\title{
Created goodness and the goodness of God: divine ideas and the possibility of creaturely value
}

\author{
Dan Kemp (D) \\ Department of Philosophy, Baylor University, 1 Bear Place, Waco TX, 76798, USA \\ e-mail: dan_kemp1@baylor.edu
}

(Received 29 July 2020; revised 25 January 2021; accepted 23 January 2021)

\begin{abstract}
Traditional theism says that the goodness of everything comes from God. Moreover, the goodness of something intrinsically valuable can only come from what has it. Many conclude from these two claims that no creatures have intrinsic value if traditional theism is true. I argue that the exemplarist theory of the divine ideas gives the theist a way out. According to exemplarism, God creates everything according to ideas that are about himself, and so everything resembles God. Since God is wholly good in every way, and since ethical supervenience is true, it follows that creatures have intrinsic value.
\end{abstract}

Keywords: Theism; Metaethics; Intrinsic Value; Divine Ideas

\section{Introduction}

Common sense tells us that ordinary things have value. Family, friends, fulfilling work, and acts of charity are just a few examples of day-to-day things that we call good. Some have recently argued that traditional theism rules out the possibility that creatures have value in virtue of their intrinsic features, a property commonly referred to as intrin-

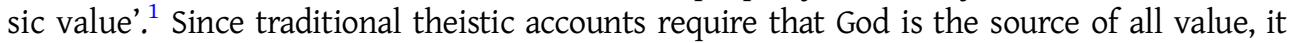
seems to follow that all creaturely value is extrinsic. Thus, traditional theism apparently requires that only God can be intrinsically valuable. Linda Zagzebski says, 'To the theist, the goodness of everything ultimately comes from the goodness of God, so in a sense the goodness of everything in this world is extrinsic' (Zagzebski (2004), 83). Because of arguments like this one, many look to relational accounts of creaturely value like the one developed by R. M. Adams in Finite and Infinite Goods. To Adams, creaturely goodness is a relation of resemblance between the thing's nature and its Maker. God is the Good, and creatures are good because they resemble him (Adams (1999), ch. 1). No creature has intrinsic value.

In this article, I argue that traditional theism is compatible with creaturely intrinsic value. This is seen by observing another traditional theistic doctrine. The classical theory of divine ideas says that God's ideas are (i) the patterns according to which creatures are made, and are (ii) about himself. God gets the ideas of creatables by thinking of himself. Nothing had by creatures is absent in God. Thus, everything that exists exactly resembles something about God. If we add to this doctrine two plausible premises, that the moral supervenes on the non-moral and that God is intrinsically good in every way that he

(c) The Author(s), 2021. Published by Cambridge University Press. This is an Open Access article, distributed under the terms of the Creative Commons Attribution licence (http://creativecommons.org/licenses/by/4.0/), which permits unrestricted re-use, distribution, and reproduction in any medium, provided the original work is properly cited. 
exists, it follows that goodness is intrinsic to creatures. Contra Adams, creatures have a type of goodness that is not reducible to their resemblance to God. Rather, their goodness is a feature that resembles God.

Here is how the article will proceed. First, I will distinguish intrinsic value from final value, which is the feature a thing has of being desirable as an end. Then I will lay out the argument for the incompatibility of traditional theism and creaturely intrinsic value in more detail. Anyone who accepts this argument as sound should also accept a similar and far more worrisome argument for the incompatibility of traditional theism and creaturely final value. Fortunately, as I will show, both of these arguments fail, given the traditional account of divine ideas. The first fails because the traditional account of divine ideas, together with two other premises widely held among theists, entails that creatures have intrinsic value. The second argument fails because the traditional account of divine ideas prompts yet another distinction between internal and external final goods. God is the end of all creaturely value in an extrinsic sense, but it does not follow from this that all creaturely value is instrumental.

\section{The problem}

\section{Value and theistic explanations}

A thing can be valuable for itself or as a means to something else (or both). A thing can also be valuable in virtue of itself or in virtue of something extrinsic to it (or both). ${ }^{2}$ For our purposes, we will work with the following two definitions.

Final Value: Some $x$ has final value if and only if $x$ is desirable for its own sake. Intrinsic Value: Some $x$ has intrinsic value if and only if one or more of the intrinsic features of $x$ are sufficient to make it finally valuable.

Notice that if something has intrinsic value, then it also has final value. This will be important later. But if it has final value, it does not necessarily have intrinsic value. For example, one may go through a great deal of trouble to acquire a bad painting by a famous artist because it was recently discovered to be his last work. The painting is valuable for itself, since the person who bought it did not get the painting for any further purpose. The source of the painting's value, however, is the relation in which it stands to extrinsic circumstances; in this case, the fact that it was a famous painter's last painting. The painting, then, has extrinsic and final value.

A value provides a kind of explanation for action. Traditional theism, moreover, holds that all explanations must ultimately end with God, since nothing can be independent of God. If something did exist independently of God, and this independent thing interacted with and partly explained elements of God's creation, then God's relationship to this thing would not be that of a Creator to creature but more like a peer to peer. Traditional theism, however, claims that God is the first cause of everything other than himself and therefore explains everything other than himself. Traditional theism, then, puts a strong constraint on what must be the ultimate explanations of things. That constraint is expressed in the following principle.

Principle of Theistic Explanation: Everything that can be explained must ultimately be explained by God or be God.

Explanations are ways of answering 'why' questions, and traditional theism historically adopted Aristotle's four ways of asking and answering such questions. If we ask why 
some phenomenon occurs or exists, we may be told about the agent that brought it about (efficient cause), or the purpose for which it was brought about (final cause), or the form or the nature that makes it what it is (formal cause), or the stuff out of which it was made (the material cause). For instance, if one asks for an 'explanation' of Lady Liberty, the answer is, roughly, that certain people made an image of a lady holding a torch and a tablet from copper (and other materials) to symbolize certain values shared by France and the United States. This reply involves the four kinds of explanations.

Traditional theists like Aquinas refused to explain finite phenomena with God as material cause or formal cause in the strict sense (Aquinas (1948), I q. 44). This kind of theism is committed to the absolute distinction between creature and Creator. If the matter of an object is that out of which it is made and the formal cause is its nature, then thinking of God as either the material cause or the formal cause of creatures would contravene the creature-Creator distinction. Yet Aquinas recognizes a qualified sense in which God can be the formal cause of creatures as their exemplar (Doolan (2008), ch. 5). Thus, the sense of explanation at work in the principle is threefold. First, theistic explanations reveal how God is the source of all things. Creatures possess only those real features that are first essentially possessed by God who gives them to us. Traditionally, this point has been expressed by calling God the 'first efficient cause' of everything that exists. Second, God is the end of all things. This point is usually made by calling God the 'first final cause'. Finally, the forms or natures that creatures instantiate are copies of God himself as their exemplar formal cause. All three of these types of explanation are complete in that they span the whole of finite reality.

\section{The problem of intrinsic value and theistic explanations}

Take the highly abstract fact that some creaturely thing has value. According to traditional theism, God is the ultimate explanation of this fact. It is one thing to hold that God explains creaturely value by creating creatures that have value, it is quite another to hold that God explains the abstract fact that the thing is good. This second commitment of traditional theism presents a problem for creaturely intrinsic value. If God explains some creature's value in this second sense, then it seems to follow that none of its intrinsic features are sufficient to make it finally valuable. The value a thing has requires some further relation to God. Nothing with intrinsic value can have value in virtue of only extrinsic features, however. The worry, then, is that since theistic explanations of creaturely value entail that it must be extrinsic, it follows that there is no creaturely intrinsic value. The argument can be stated in the following way.

1. All creaturely value is explained by God. (Principle of Theistic Explanation)

2. Some $x$ has intrinsic value if and only if at least one of the intrinsic features of $x$ is sufficient to make it finally valuable. (Intrinsic Value)

3. Creaturely value is explained by God only if to have creaturely value is to stand in some relation to God. (premise)

4. Therefore, to have creaturely value is to stand in some relation to God. (from 1 and 3 ).

5. If for $x$ to have value is for $x$ to stand in some relation to $y$ that is not $x$ or any part of $x$, then no intrinsic feature of $x$ is sufficient to make $x$ finally valuable. (premise)

6. Therefore, if for $x$ to have value is for $x$ to stand in some relation to $y$ that is not $x$ or any part of $x$, then $x$ does not have intrinsic value. (from 2 and 5)

7. Therefore, no creature has intrinsic value. (from 4 and 6)

Some accept this argument as a reductio against any view that holds to the Principle of Theistic Explanation. ${ }^{3}$ Others accept the conclusion of (1)-(7) and bite the bullet. ${ }^{4}$ 
These are not our only options, however. Although I will eventually argue that we should reject premise (3), a certain kind of theist might object to (5) on the basis that it assumes the so-called 'Loneliness Principle', the principle that relata are prior to the relations that obtain among them. Indeed, the Thomistic strand of theism that I will discuss later denies this claim. Without Loneliness we could allow the theist to hold that the good-making features of $x$ are both intrinsic to $x$ and obtain in virtue of its relation to God who is not $x$. Some may be open to this possibility, but it is a hard pill to swallow for many to whom the Loneliness Principle is simply incorrigible. Moreover, merely rejecting Loneliness would not avoid the problem of creaturely final value presented in the next section.

\section{The problem of final value and theistic explanations}

As I mentioned above, some theists may be inclined to accept the conclusion that no creatures have intrinsic value. This concession is made palatable by the distinction between final value and intrinsic value. People have strong intuitions that certain creaturely things are valuable. They do not have obvious intuitions about that in virtue of which they are valuable. What is most important, then, is that there is room for creaturely final value on a theistic account..$^{5}$ Unfortunately for this attempt to save the Principle of Theistic Explanation from the reductio, the argument of (1)-(7) against creaturely intrinsic value can be modified to show that the Principle also rules out creaturely final value.

8. All creaturely value is explained by God. (Principle of Theistic Explanation)

9. Some $x$ has final value if and only if $x$ is valuable for its own sake. (Final Value)

10. All creaturely value is explained by God only if creatures have no end apart from God. (premise)

11. Therefore, creatures have no end apart from God. (from 8 and 10)

12. If $x$ has no end apart from $y$ that is not $x$, then $x$ is not valuable for its own sake. (premise)

13. Therefore, no $x$ has final value if no $x$ has any end apart from $y$ that is not $x$. (from 9 and 12)

14. Therefore, no creature has final value. (from 11 and 13)

I mentioned earlier that some might want to avoid the argument against creaturely intrinsic value by rejecting Loneliness. However, the argument (8)-(14) rules out this potential move because the argument against creaturely final value gives us a second argument against creaturely intrinsic value that doesn't depend on Loneliness. Recall that our definitions entail that if something has intrinsic value, then it has final value. But if the argument (8)-(14) is sound, then there is no creaturely final value. If (8)-(14) is sound, it follows that there is no creaturely intrinsic value either, irrespective of whether Loneliness holds. Since no premise of the argument against creaturely final value depends on Loneliness, the theist therefore cannot save creaturely intrinsic value by denying Loneliness.

The argument of (1)-(7) is modified to account for the different kind of explanatory relationship called for by final value. Anyone who accepts (1)-(7) should also accept (8)-(14). It may be objected that (8)-(14) is significantly different from (1)-(7) in that it has different premises that can be challenged on different grounds. This second argument claims that a theistic explanation of creaturely value requires that creatures have no end apart from God. Nothing in argument (1)-(7) asserts anything like this. Indeed, one might reject premise (10) on the grounds that God need not be the end of a value to explain it. But this is wrong. Earlier I claimed that the end of a thing is its final cause, which is an explanans of one of the four kinds. Thus, if God is not the end of a thing, then there is one 
sense in which he doesn't explain it. But the Principle rules this out. Similar to the case of intrinsic values, it seems that final values cannot have explanations of this sort by definition. They cannot, in other words, be explained by further ends. So it appears that we must choose between creaturely final value and the Principle.

At this point, the theist might go back and object that the Principle is too strong. She might concede that God does not explain creaturely value in one respect, insofar as some creatures have some ends other than God. Reasonable as this sounds, this is a fatal mistake for the theist to make. This view implies that whatever final value creatures have is in one sense independent of God. In that case, God may still bear on our deliberations as a prudential matter. He might, for instance, ensure that any ultimate aim other than himself is futile or met with punishments. That condition would give everyone good reason to make God the ultimate end of all their pursuits, and anyone who fails to do so would be irrational. ${ }^{6}$ Yet the answer to the question, 'Why is such-and-such desirable?' would nevertheless have nothing to do with God. The reason is because this view makes 'the will of God our rule', as William Paley quipped, and 'private happiness . . o our motive' (Paley (1815), 59). God serves more as a constraint on our ends rather than as the source of them. But this is unacceptable to the theist. There is no possible good independent of God, and not just because God necessarily punishes those who fail to pursue him, but because creatures are necessarily fulfilled in God alone. ${ }^{7}$ We can also give a quick Anselmian argument here. A being who cannot fail to be the end of all creatures and creaturely states, and therefore all valuable ones, is greater than a being who can. Thus, God cannot fail to be the end of all creatures and creaturely states. And since the consequent of premise (10) is true, the whole conditional is true. It seems, then, that God must explain all creaturely value as an end explains what aims at it.

The argument (8)-(14) purports to show that the Principle of Theistic Explanation rules out creaturely final value. If so, traditional theism comes at a very high cost given powerful intuitions that at least some creatures have final value. Some theists might think that, say, virtue or friendship are valuable on account of God, and therefore have instrumental value. But these cases seem to contrast with cases of mere instrumental value, such as the act of taking an Aspirin to cure a headache. It does not even seem intelligible to say that God is the end for which virtue or friendship are a means in the same way that headache relief is the end for which taking the Aspirin is a means. While the theist may appear to escape the initial objection by conceding that there is no creaturely intrinsic value, it is not so easy to make this concession about creaturely final value. Something has therefore gone wrong with one of the premises, since they imply a false conclusion. ${ }^{8}$

Yet there is a way out for the theist, since he has good reason to reject (3) and (12). As far as I can tell, these two premises do not necessarily stand or fall together. But the argument I will make against one will knock out the other. Even if one is not persuaded by my move from the argument against creaturely intrinsic value to the argument against creaturely final value, he or she can at least accept from what follows that the theist need not reject creaturely intrinsic value.

\section{The solution}

\section{The exemplarist doctrine of divine ideas}

I think there is an adequate reply to these objections against creaturely intrinsic value and final value. This reply, moreover, comes from a robust doctrine of creation according to which creaturely natures are copies of the Creator who is the Good. The appeal to a doctrine of creation should not be a surprise given the theistic rejection of the sort of 
Platonism that says the Good (i.e. God) is a property of good things. God is not a property, so he cannot be the property creatures possess that makes them good. So if creatures have any goodness at all, God must create it. In the next section, I argue that this doctrine of creation with two other plausible premises entails that creatures are valuable by virtue of their natures, that is, in virtue of their intrinsic features. After that, I distinguish between 'internal' final value and 'external' final value, and then argue on the basis of this distinction that creaturely states have internal final value while the Principle of Theistic Explanation only requires that God must be the external end of all things. In this first section, I briefly lay out the doctrine of creation that will do the heavy lifting in these arguments.

The divine ideas play a crucial role in any traditional theistic doctrine of creation. Theists have found it important to hold that God was not flying blind when he made the world, only to discover what he had made once he finished. ${ }^{9}$ Traditional arguments for the divine ideas emphasize the absurdity of supposing that an artisan can create without ideas. ${ }^{10}$ Everything we know about the process of making things gives us reason to think that the maker must have some idea of the product before intentionally setting about to make it. It seems absurd to say that the carpenter made the table on purpose but had no idea of what a table is. Likewise, we need to hold that God has ideas of what he makes if we are to explain creation in a way compatible with orthodox theism. And so if God had knowledge about the sorts of things he could and would create, then he had ideas of creatable things.

Voluntaristic divine conceptualism about divine ideas claims makes them up (Leftow, 2012). What has been called the 'classical theory' of divine ideas says that ideas come from God himself as their exemplar (Ward (2020), 22). ${ }^{11}$ God generates the ideas by thinking about himself, and so his ideas are ideas about himself. There are two main versions of exemplarism. To put it briefly, what can be called 'imitative exemplarism' says that God generates the ideas by thinking of the ways he can be imitated. ${ }^{12}$ God gets the idea of a cow by thinking about the particular imitation of the divine essence that would constitute bovinity. On the other hand, Tom Ward has recently developed a view along Scotist lines that he calls 'containment exemplarism' which says that the divine ideas are about parts or aspects internal to God himself (Ward $(2020,41)$. God has the idea of a cow by thinking of himself, which contains bovinity as a part. ${ }^{13}$ What fundamentally unites classical theories of divine ideas is (i) that nothing exists or obtains prior to or alongside God, (ii) that anything that exists or obtains that is other than God is explained by God, and (iii) that God always knows what he's doing when he generates anything (including his ideas). So classical theories of divine ideas, or 'exemplarisms' as we can refer to them, make the following claim.

Exemplarism: God's ideas of creatable things are about himself.

If we also grant that all things other than God are created by God, which an exemplarist will, then it follows from exemplarism that all things essentially resemble God. ${ }^{14}$ Imitation exemplarism says that all things resemble God insofar as they imitate the divine essence. God thinks of the ways he can be imitated, and from that process gets ideas of the different possible things that can imitate him. His idea of the way a possible creature imitates him is prior to his idea of the possible creature itself. Imitation exemplarism thus denies the Loneliness Principle. Containment exemplarism, on the other hand, says that all things resemble some aspect or part internal to God. On this view, God has in mind the part of himself that can be imitated, and so can be possibly imitated in various ways. On this view, Loneliness is affirmed. Both views, however, agree that when God makes creatures, he makes things that are essentially like himself insofar as his idea of them is an idea of himself. 
This likeness between creature and Creator amounts to a kind of identity, though we must take great care here concerning what type of identity holds between which things. We can't mean token-identity, because traditional theism posits an absolute distinction between creature and Creator. Neither can we mean type-identity, since doctrines of divine ideas compatible with traditional theism make God responsible for the existence of types, and exemplarism does so by having God think of himself in one way or another. The answer is that creatures are exactly similar to some aspect or part of God (Ward (2020), 53-55). Of course, exact similarity does not hold between all the features of a creaturely nature and the corresponding part of God, since the latter is related to God in a different way than the former is related to the creaturely individual. Nonetheless, exact similarity of the natures themselves is entailed by exemplarism, otherwise there would be something - whatever isn't exactly similar - that God does not explain. For whatever genuinely real thing we can identify in the world, it is exactly similar to some aspect or part of God.

These commitments of exemplarism mean that certain formal features of creatures are not explained by God, though their instantiation in an actual creature is. On exemplarism, God explains why my dog Maple exists, but he does not explain Maple's caninity, which, on exemplarism, is itself an aspect of God. The caninity that Maple has, then, is explained by God only insofar as it is instantiated in a finite, concrete individual. The caninity that Maple has abstractly, however, is not. Take a more common example of the conditional 'If Dan is human, then Dan is risible.' If exemplarism is true, then this conditional is not explained by God, despite the fact that God explains the risibility I actually instantiate. On the contrary, the conditional is true in virtue of something that $I$ have that exactly resembles some aspect of God. Thus, there is a set of creaturely features that are immutable and eternal, and essential to any creature that instantiates them, such as 'being risible' is for humans. My move in the next two sections will be to argue that intrinsic and final values are to be included in this set.

\section{Exemplarism and a theistic explanation of intrinsic value}

Now that we have briefly summarized the exemplarist doctrine of divine ideas, we can get the basic argument for creaturely intrinsic value on the table. In addition to exemplarism, the argument relies on two other premises. The first is a strong claim about God's goodness, which is that everything about God, in God, part of God, or whatever, is intrinsically good. In brief, God cannot fail to have intrinsic value in any respect. We can call this the 'maximal goodness' thesis. This view has an impressive record among theists. Boethius says, 'For It [God], in every way that It is, is Good in this, that It is. For It is nothing other than the Good. ${ }^{15}$ We also find it in contemporary writers. William P. Alston, for instance, says that because God is the supreme ethical standard, 'goodness supervenes on every feature of God' (Alston (2002), 290). ${ }^{16}$ The question is settled for the theist, yet again, by an Anselmian argument. A being whose every aspect is intrinsically good is greater than a being who has an aspect that fails to be good.

The other premise is a broad notion of ethical supervenience that is accepted by nearly everyone. Supervenience about intrinsic goodness is the doctrine that if $A$ is intrinsically good and $B$ is exactly similar to $A$ in every respect other than its intrinsic goodness, then $B$ is also intrinsically good. I can say little to defend this premise here, other than to note that ethical supervenience has been called 'the least controversial thesis in metaethics' (Rosen (2020), 205). ${ }^{17}$ Additionally, supervenience is entailed by the mediaeval view of the convertibility of being and goodness, according to which being and goodness refer to the same thing strictly speaking (Aquinas (1948), I., q. 5, a. 1.). And this implies the logical covariance of having some property and the supervening value. And since 
supervenience of the moral on the non-moral only requires logical covariance of having some moral property and being some $F$, this is all I need for my argument to work. Convertibility entails supervenience.

The doctrine of convertibility obviously denies the existence of non-axiological (or 'non-moral') properties in the world, but this is not a problem for the view. It allows us to describe the world in evaluative or non-evaluative ways. Ethical supervenience has been cast in terms of descriptions rather than facts and properties (Jackson (1998), 119). Similarly, we can think of a being in a non-evaluative way. 'He took the pears from his neighbours', for instance, is a non-evaluative description. Since a thing's being and its goodness are the same thing, two things that have the same nature will have the same value. Although the doctrine of convertibility rules out non-moral things, it assumes a distinction between moral and non-moral descriptions.

Granting maximal goodness and ethical supervenience, creaturely intrinsic value follows from exemplarism. Exemplarism says that God creates some $x$ according to some pattern $p$ found in himself. So $x$ is a copy of $p$ insofar as it is exactly similar to it. But this kind of theism also says that all of God is good in every respect. Therefore, $p$, whatever it is, since it is some aspect of God, it has intrinsic value. But given ethical supervenience, $x$ cannot be exactly similar to $p$ and $p$ have intrinsic value unless $x$ also has intrinsic value. Likewise, if every aspect of God is good, then anything exactly similar to any aspect of God is also good. But exemplarism says that everything is exactly similar to some aspect of God. Given ethical supervenience and maximal goodness, then, exemplarism implies that creatures are intrinsically good. We can put the argument in the following way.

15. Every aspect of God is intrinsically good. (Maximal Goodness)

16. For any creature, it is exactly similar to some aspect of God. (Exemplarism)

17. For anything $A$, if $A$ is intrinsically good, and $B$ is exactly similar to $A$ in every respect other than A's intrinsic goodness, then $B$ is also intrinsically good. (Supervenience)

18. Therefore, created things are intrinsically good. (from 15,16 , and 17)

Is the conclusion of this argument compatible with the Principle of Theistic Explanation? Recall that for the Principle to be satisfied, either of two things must be true. Either the thing in question must be explained by God or it must be God. On the view I'm putting forward here, there are elements of both involved in the account of creaturely intrinsic value. That $F$ is a good-making feature is a fact about God, just as the fact that humanity entails risibility is a fact about God. The fact that there are any $x$ 's at all that are $F$ such that there are finite goods is explained by God. The infinite Good made finite copies of itself. The copies therefore participate in the divine, insofar as they are made according to natures found in God, and they are also explained by God, insofar as they are his creations.

The view I present here differs crucially from relational accounts of creaturely goodness like R. M. Adams's, according to which creaturely goodness is identified with resemblance to God (Adams (1999), ch. 1). If we accept Loneliness, Adams's view is incompatible with creaturely intrinsic value, whereas exemplarism (together with the other premises above the exemplarist is likely to make) entails it. Recall that premise (3) in the argument against creaturely intrinsic value says that creaturely value is explained by God only if to have creaturely value is to stand in some relation to God. The exemplarist about divine ideas need not accept this premise, however. On this view, God makes creatures and they are good because of features copied from himself. Moreover, like the goodness of what is copied in God, the goodness of these creaturely features is 
intrinsic to them. The case is analogous to other aspects of created beings. A creature is good because of its relation to God no more nor less than it has its nature in virtue of some relation to God. The particular risibility instantiated by a human is copied from the divine essence, but it is not extrinsic to the human that instantiates it. Likewise, the particular goodness instantiated by a human is copied from an aspect or part of God, and it also is not extrinsic to the human that instantiates it. Of course, exemplarism entails that creatures necessarily resemble God, and so their goodness necessarily stands in relation to God. Nonetheless, their goodness is not extrinsic to them.

One may nevertheless suspect that exemplarism fails to get creaturely intrinsic value off the hook. If my argument is simply that creaturely goodness is logically implied by exemplarism, supervenience, and maximal goodness, it apparently amounts to no more than the view that some creaturely $x$ is good because it has $F$. And this would seem so, since by definition intrinsically good things have some intrinsic feature $F$ that sufficiently makes them good, and so sufficiently explains their goodness. So my view seems to imply at least one kind of fact that is not explained by God after all: that $F$ is a good-making feature.

The forgoing states the upshot of my argument; it doesn't object to it. The Principle does not simply assert that everything must be explained by God, full stop. On exemplarism, the fact that to be human is to be risible is not explained by God strictly speaking. Insofar as we think this property is a feature of human nature, the fact is about God himself. My claim is that at least some of the good-making features of creatures are in the same boat. If it is a problem that actual creatures are good because they have $F$, then it is also a problem that humans are risible because of their humanity. My solution is simply an extension of the doctrine of creation. It brings with it no problem not already contained in it.

\section{Exemplarism and a theistic explanation of final value}

Something has intrinsic value only if it has final value. ${ }^{18}$ If the argument of (15)-(18) concluding that creatures have intrinsic value is sound, then, it follows that creatures have final value. This argument, however, does not touch the argument of (8)-(14) against creaturely final value, which threatens creaturely intrinsic value. The theist who wants to preserve creaturely intrinsic value thus needs a way to defeat this second argument and preserve creaturely final value. I will give such an argument in this section.

If we accept supervenience about intrinsic goodness, we should accept it about final goodness as well. If $A$ is finally good and $B$ is exactly similar to $A$ in every respect other than its final goodness, then $B$ is also finally good. Moreover, if we accept the maximal goodness thesis, then we should also accept the claim that every aspect of God is itself desirable. The distinction between intrinsic value and final value is supposed to show that one can have the latter without the former, but not vice versa. If something is intrinsically valuable, then it is also finally valuable. Thus, if one accepts maximal goodness - the claim that every aspect of God is such that it is finally valuable in virtue of some intrinsic feature - one should, on pain of inconsistency, accept the weaker claim that every aspect of God is finally valuable.

With these two modifications, let's return to the basic argument given before. Applied to final value, the argument works as follows.

19. All of God is finally good. (Maximal Goodness)

20. For any creature, it is exactly similar to some aspect of God. (Exemplarism)

21. If $A$ is finally good and $B$ is exactly similar to $A$ in every respect other than its final goodness, then $B$ is also finally good. (Supervenience)

22. Therefore, created things are finally good. 
Again, the big question here is whether this argument is compatible with the Principle of Theistic Explanation. Doesn't the argument imply that there are some facts, such as the fact that any human is finally valuable, which are not explained by God? The answer is yes, but as before this does not mean the argument violates the Principle, which entails only that God is the final explanation of everything. The final value of $x$ is what $x$ is finally aimed at, which can be internal or external to $x$. By this we typically mean that $x$ can have either final or instrumental value. If $x$ 's final value is internal, then it has final value, meaning $x$ is aimed at itself in some respect, such as what it may or should become. The examples of internal final causes are numerous. Fertilized acorns develop into oak trees, the virtuous person is what the child should become, and so on. Alternatively, $x$ is merely aimed at final value, but doesn't have it, if such value is external to $x$. It is tempting to see external final value as that to which something can only be an instrument. Intuitively, if final value is external to $x$, the relationship between the value and $x$ is the relationship of an end to a means.

God himself cannot be the internal final end of any creaturely thing because God himself cannot be obtained by anything except God. But the fact that God cannot be the internal final end of any creaturely thing does not imply that creatures are only valuable as means. Likewise, to infer the universal instrumental value of creatures from the impossibility of internal final value would be a mistake. It doesn't follow that if God is an end, and is not the end we strive to become, then he must be the end for which creatures are the mere means. The inference ignores the proposal that God's value is externally final to creatures. It assumes that the only relationship $x$ can have to final value that it does not possess is instrumental. But resemblance is another possible relationship. Creatures aim to become something that is godlike. This opens up the possibility of a twofold final goodness of all things. One is external to all creatures and not possessed by them (God), and one is internal and possessed by creatures (a godlike state of themselves). Further, if $x$ has an extrinsic final good $G$ to which it is related by resemblance, then $x$ has an internal final good. The internal good of $x$ constitutes the creaturely relatum in the resemblance relation to $G$. Crucially, however, creaturely goodness is primarily attributed to the relatum, not the relation.

Before, we noticed that we can distinguish between two sorts of formal causes, one internal and one external or 'exemplary', and that God is the latter but not the former for creatures. We can make a similar distinction for final causes. A thing's final cause properly speaking is what it aims to become. In doing so, however, things aim to become like something else, God, who is their extrinsic or exemplar final cause. For the exemplarist, this resemblance is the result of the divine ideas. The classical theory of divine ideas says that God is the source of his ideas, and so he gets them by thinking of himself. The final (internal) end a thing pursues, then, is something created according to an idea in the mind of God that he gets by thinking of himself. That towards which creatures strive is a creaturely state that resembles God. As in the case of intrinsic value, God does not explain these ends any more than he explains why humans are risible or why snakes are coldblooded. These facts are firstly about God himself and are transmitted to finite beings by way of creation according to the divine ideas.

Here I think Aquinas is helpful. Towards the end of the article answering the question 'Whether All Things Are Good by the Divine Goodness?' Aquinas says, 'everything is called good by reason of the similitude of the divine goodness belonging to it, which is formally its own goodness' (Aquinas (1948), I, q. 6, a. 4). There are at least two ways to read this passage. The first amounts to Adams's view. A creature is good because it resembles God, meaning that creaturely 'good' refers to a resemblance to God. A second reading, however, is suggested by the previous sentence in the passage, that creatures are 'called good from the divine goodness, as from the first exemplary effective and final principle of 
goodness. ${ }^{19}$ I suggest that one plausible reading of this passage is that exemplarism is being invoked by Aquinas to explain how goodness is intrinsic to creatures and also depends on God's goodness. God is the exemplar from which things are copied, so all things are good from God in the sense that his goodness is copied in all things. Their goodness is their own no less than their existence. Given this reading, it is natural for Aquinas to conclude the section by saying, 'And so of all things there is one good and yet many goodnesses.' The many goodnesses are not resemblances to God, but finite beings that resemble God.

All this provides a way to save the theist from the argument (8)-(14) above. Given the discussion here, premise (10) needs to be disambiguated between the internal and external senses of final goodness. It clearly can't take on the internal sense, as that would amount to saying that God only explains creaturely value if creatures aim to become God, which is surely not a constraint theism puts on explanations of creaturely final value. Thus, we should modify premise (10) in the following way.

10*. All creaturely value is explained by God only if creatures have no external end apart from God.

But then, to make the argument valid, we have to change premise (12) to the following.

$12^{*}$. If $x$ has no external end apart from $y$ that is not $x$, then $x$ is not valuable for its own sake.

Premise $\left(12^{*}\right)$, however, is not a conceptual truth, as (12) was presented to be. We have seen that there are two types of external ends: one for which the aiming thing is a means to and the other for which the aiming thing is meant to become like. In the second case, God is the end of creaturely final value the way something imitated is the end of an imitator. Thing $x$ is an external final cause for thing $y$ if the end of $y$ is to become like $x$, but $y$ is not thus an instrument to $x .^{20}$ Thus, something that has an external final cause is not necessarily a means to it. Premise $\left(12^{*}\right)$ is false.

\section{Conclusion}

Creaturely intrinsic value and final value follow from exemplarism, maximal goodness, and a broad notion of ethical supervenience. Creaturely goodness is not simply the resemblance a creature has to God, but a state that resembles God. It at least shows that a theistic explanation of finite value is compatible with creaturely intrinsic value and final value. It also shows that traditional theism is compatible with the view that moral facts could only be explained, if they can be explained at all, by other moral facts (Heathwood 2012). If God is the Good, then certain ways of speaking about God are irreducibly evaluative. And since creatures are copies of the Good, their good is likewise irreducible. Creatures are good because of the features they have, which are ways of resembling God. Creaturely goodness is not the resemblance itself, however, but the thing that resembles. We are not merely God's instruments, but we are also not good in any way independent of God. The gifts of God are only gifts in God. George Herbert puts it well.

'But to have nought is ours, not to confess

That we have nought.' I stood amaz'd at this,

Much troubled, till I heard a friend express

That all things were more ours by being His. ${ }^{21}$ 


\section{Notes}

1. See Murphy $(2018,349-351)$ and Wielenberg $(2014,80-85)$ and (2018). Only Wielenberg thinks this result makes such views unacceptable. This also seems to be one of the central concerns of Lewis (1960).

2. See Korsgaard (1983). Korsgaard's scheme entails that there is no intrinsic value that is not also either instrumental or final. Some may doubt that a thing's instrumental value can be intrinsic to it. Even for those who don't, the topic of this article can be interpreted to be about the kind of final goodness that is also intrinsic.

3. See Wielenberg $(2014,44)$. Shafer-Landau (2010, 60-65) argues similarly.

4. See Murphy $(2018,351-353)$ and Zagzebski $(2004,83)$.

5. This is Murphy's main argument $(2018,351)$.

6. See Geach (1969) for this view as an explanation of deontic properties.

7. Murphy $(2011,95-97)$ argues that theistic ethical theories that do not make God an 'immediate' explanation of moral facts have a problem of 'divided loyalties.'

8. Murphy (2018) agrees that there is a strong intuition of creaturely final value. Aquinas, moreover, says that 'all desire their own perfection', suggesting that the perfection of each thing is itself desirable $(1948,1$, q. 6, a. 1). My thanks to a referee for pressing me on this point.

9. Although some theists argue that God did create in this manner.

10. See Augustine (1982, Question 46), Anselm (2007, chs 9-10), Aquinas (1948, 1, q. 15, a. 1), and Vermigli (2006, 137-141).

11. Greg Welty holds a similar view, according to which God's ideas originate from the range of his power (2014,

89). My thanks to a referee for pointing this out.

12. See Aquinas (1948, I, q. 15, a. 2) and Doolan (2009, ch. 3).

13. The imitative view agrees with Ward that the divine essence contains, e.g., bovinity (Aquinas 1948, I, q. 4, a. 3). What is distinctive of Ward's view is that the divine essence contains bovinity as a part or an aspect.

14. It might be objected that deviant properties of creatures (e.g. deficient, lacking, evil) do not exist in God, but exemplarism entails that deviant properties do not have real being.

15. Quoted in Aquinas $(2001,51)$.

16. Although Alston accepts the claim for reasons that may not be compatible with my argument.

17. Quoted from McPherson (2019).

18. See note 2 .

19. Emphasis mine.

20. Creatures are instruments for God. But they are not merely instruments.

21. My thanks to C. Stephen Evans, Derek Haderlie, Keith Hess, Anne Jeffrey, Harrison Lee, Justin Morton, Tom Ward, and two anonymous referees for their comments on earlier drafts of this article.

\section{References}

Adams RM (1999) Finite and Infinite Goods: A Framework for Ethics. New York, NY: Oxford University Press.

Alston WP (2002) What Euthyphro should have said. In Lane Craig W (ed.), Philosophy of Religion: A Reader and Guide. New Brunswick, NJ: Rutgers University Press, pp. 283-298.

Anselm (2007) Monologion. In Anselm: Basic Writings. Williams T (trans.). Indianapolis, IN: Hackett Publishing, pp. $1-73$.

Aquinas T (1948) Summa theologica. Fathers of the English Dominican Province (trans.). New York, NY: Benziger.

Aquinas T (2001) An Exposition of the 'On the Hebdomads' of Boethius. Schultz JL and Synan EA (trans.). Washington, DC: The Catholic University of America Press.

Augustine (1982) Eighty-Three Different Questions. David L. Mosher (trans.). Washington, DC: The Catholic University of America Press.

Doolan GT (2008) Aquinas on the Divine Ideas as Exemplar Causes. Washington, DC: The Catholic University of America Press.

Geach P (1969) The Moral Law and the Law of God. In God \& the Soul. London: Routledge and Kegan Paul, pp. 117-129. Heathwood C (2012) Could Morality Have a Source? Journal of Ethics and Social Philosophy 6(2), 1-19.

Jackson F (1998) From Metaphysics to Ethics: A Defense of Conceptual Analysis. Oxford: Oxford University Press.

Korsgaard CM (1983) Two Distinctions in Goodness. The Philosophical Review 92, 169-195.

Leftow B (2012) God and Necessity. New York, NY: Oxford University Press.

Lewis CS (1960) The Four Loves. New York, NY: Harcourt, Brace.

McPherson T (2019) Supervenience in Ethics. In Zalta E (ed.), Stanford Encyclopedia of Philosophy. Available at https://plato.stanford.edu/entries/supervenience-ethics/ (accessed 19 March 2020).

Murphy M (2011) God and Moral Law: On the Theistic Explanation of Morality. New York, NY: Oxford University Press. 
Murphy M (2018) No creaturely value. Philosophica Christi 20, 347-355.

Paley W (1815) Principles of Moral and Political Philosophy. 8th American Edn. Boston MA: West and Richardson. Rosen G (2020) What is normative necessity? In Dumitru M (ed.), Metaphysics, Meaning, and Modality: Themes from Kit Fine. New York NY: Oxford University Press, pp. 205-233.

Shafer-Landau R (2010) The Fundamentals of Ethics. New York, NY: Oxford University Press.

Vermigli PM (2006) Commentary on Aristotle's Nicomachean Ethics. Campi E and McLelland JC (eds), Giulio Santerenziano (trans.). Kirksville, MO: Truman State University Press.

Ward T (2020) Divine Ideas. New York, NY: Cambridge University Press.

Welty G (2014) Theistic conceptual realism. In Gould PM (ed.), Beyond the Control of God?: Six Views on the Problem of God and Abstract Objects. New York NY: Bloomsbury Academic, pp. 81-112.

Wielenberg E (2014) Robust Ethics: The Metaphysics and Epistemology of Godless Normative Realism. New York, NY: Oxford University Press.

Wielenberg E (2018) Reply to Craig, Murphy, McNabb, and Johnson. Philosophia Christi 20, 365-375.

Zagzebski L (2004) Divine Motivation Theory. New York, NY: Cambridge University Press.

Cite this article: Kemp D (2022). Created goodness and the goodness of God: divine ideas and the possibility of creaturely value. Religious Studies 58, 534-546. https://doi.org/10.1017/S0034412521000032 